\title{
SERHAN V. JOHNSON \& JOHNSON: A CASE COMMENT
}

\author{
RUSSELL BROWN AND MON A. YAHYA
}

\section{INTRODUCTION}

The recent pronouncement of Cullity J. of the Ontario Superior Court granting an order for class certification in Serhan v. Johnson \& Johnson' is the latest in a series of decisions since the Supreme Court of Canada expanded tort law's boundaries in Winnipeg Condominium Corp. No. 36 v. Bird Construction $\mathrm{Co}^{2}$ to embrace claims arising from a defect in (as opposed to damage caused by) a product or building structure. In Serhan, the defendant, Johnson \& Johnson, manufactured and marketed a blood glucose monitoring system, which consisted of meters ("SureStep meters") and "Strips" to be used when testing blood. In some cases, the SureStep meters allegedly failed to register the existence of high glucose levels, and instead displayed either an erroneously low reading or an error message. While Johnson \& Johnson knew of the problem, it is alleged to have refrained from taking corrective measures until various U.S. agencies, including the Department of Justice, the FBI and the FDA, had commenced investigating consumer complaints. Ultimately, it paid a fine of over US\$29 million and was forced to pay settlements initiated by whistleblower employees in its Canadian division.

As we will describe in this comment, however, Serhan represents not an application of Winnipeg Condominium, but an extension of its ambit (although perhaps inadvertently so, since, curiously, Winnipeg Condominium was not cited by Cullity J.). For this reason, Serhan is a troubling addition to the growing corpus of post-Winnipeg Condominium case law in the vexed area of products liability which, as John Fleming observed over 25 years ago, ${ }^{3}$ and as Stephen Waddams has more recently affirmed, "is not yet a coherent concept of our law." Further complicating matters in Serhan was the litigants' "scattergun" pleading of multiple causes of action and remedial demands which, as a strategy, has characterized the massive tobacco litigation that has recently and dramatically shaped the landscape of U.S. products liability litigation.

\section{Justice Cullity's Reasons}

In a nutshell, Cullity J. found that the representative plaintiffs and the putative class of plaintiffs, by operation of the doctrine of "waiver of tort," could assert, even in the absence of injury, damage and loss, an entitlement to other remedies. As he wrote:

Assistant Professors, Faculty of Law, University of Alberta. We are grateful to Jason Neyers for reviewing a dralt of this comment and offering helpful comments.

(2004), [2005] 72 O.R. (3d) 296 (Sup. Ct.) [Serhan].

Winnipeg Condominium Corp. No. 36 v. Bird Construction Co., [1995] I S.C.R. 85 [Winnipeg Condominium].

John G. Fleming, The Law of Toris, Sth ed. (Sydney: The Law Book Co. Lld., 1977) at 498.

Stephen M. Waddams, "New Directions in Products Liability" in Nicholas J. Mullany \& Allen M. Linden, eds., Torts Tomorrow: A Tribute to John Fleming (Sydney: 1.BC Information Services, 1998) 119 at 119. 
Waiver of tort, by that name, has not been pleaded but, as well as the general - and by themselves probably inadequate - references to good conscience, paras. 74-76 of the statement of claim do, 1 believe, allege material facts that if proven, could entitle the plaintiffs to a remedy on the basis of the doctrine. Such facts would constitule a cause of action for which the remedies of a constructive trust or, alternatively, an accounting of revenues, are claimed. Claims based on waiver of tort seck "restitution" of benefits received by the defendants, as a consequence of their tortious conduct rather than damages to compensate the plaintiffs for a loss. The basis of the doctrine is encapsulated in a passage from an American decision ...:

The point is not whether a definite something was taken away from plaintiff and added to the treasury of defendant. The point is whether defendant unjustly enriched itself by doing a wrong to plaintiff in such manner and in such circumstances that in equity and good conscience defendant should not be permitted to retain that by which it has been enriched. (Federal Sugar Refining Co. v. Uniled States Sugar Equalization Board. 265 F. 575 (S.D.N.Y., 1920), at 582).

Waiver of tort, as a cause of action, is said to have the advantage for a plaintiff that proof of loss as an element of the ton is not required. ${ }^{5}$

Given the "incoherence" observed by Professors Fleming and Waddams to prevail in this area of law generally, the muddling of legal devices that characterizes Cullity J.'s granting of an order for class certification in Serhan is perhaps unsurprising. He seemed to view waiver of tort as a cause of action in its own right, obviating the need for the plaintiffs to prove any damage, and requiring the court then to consider whether an equitable or restitutionary claim is merited. Ultimately, when Cullity J.'s order was reviewed by Ground J. (who granted Johnson \& Johnson leave to appeal), ${ }^{6}$ Ground J. - correctly, in our view concluded that Cullity J. had failed to consider certain persuasive English and Canadian case authorities which have stated the opposite conclusion. ' Specifically, both the House of Lords and the Ontario Superior Court had previously held that, while waiver of tort does indeed entail an injured party electing to treat - for purposes of obtaining redress - the facts as giving rise to another head of liability (typically an implied contract, but also other bases such as restitution), it still presupposes that a tort has been committed. ${ }^{8}$ Hence Goff and Jones' statement:

"Waiver of tort" is a mistomer. A party only waives a tort in the sense that he elects to sue in restitution to recover the defendant's unjust benefit rather than to sue in tort 10 recover damages; he has a choice of

Serhan, supra note 1 at paras. 34-35.

(2004), 135 A.C.W.S. (3d) 22 (Ont. Sup. Ct.).

Unired Australia Lid, v. Barclay's Bank Lid. (1940), [194I] A.C. I (H.L.) [United Australia]; Zidaric v. Toshiba of Canada Lid. (2000), [200I] 5 C.C.L.T. (3d) 61 (Ont. Sup. C.) [Zidaric].

See Unired Australia, ibid. at 18, where Viscount Simon L.C. stated: "When the plaintiff 'waived the tort' and brought assumpsit, he did not thereby elect to be treated from that time forward on the basis that no tort had been committed; indeed if it were to be understood that no tort had been committed. how could an action in assumpsit lie?" Similarly, in Zidaric, ibid. at 64, Cumming J. said: "[T] he socalled 'waiver of tort doctrine' is inapplicable unless the defendant has committed a tort which gives rise to a cause of action to the plaintiff. I find there is no reasonable cause of action in tort disclosed by the pleading. Further, the waiver of tort doctrine is inapplicable unless the defendant is unjustly enriched." 
alternative remedies. But the tort is not extinguished. Indeed. it is said that it is a sine qua non of both remedies that he should establish that a tort has been committed.

\section{SEARChING FOR A TORT}

Was a tort committed in Serhan? The allegation that the monitoring system was "dangerously defective" was presumably inserted in the Statement of Claim to invoke the "dangerous defects" distinction, identified by the Supreme Court of Canada in Winnipeg Condominium as giving rise to a tort law duty of care in cases of defective products or building structures. There, La Forest J. for the court restored the claim of a condominium corporation (the subsequent purchaser ${ }^{10}$ of an apartment building) against the general builder and subcontractor that had installed exterior stone cladding, some of which had collapsed, necessitating repairs. Observing that the structural defect was "not merely shoddy" but "dangerous," " La Forest J. said:

In my view, this is important because the degree of danger to persons and other property created by the negligent construction of a building is a comerstone of the policy analysis that must take place in determining whether the cost of repair of the building is recoverable in tort. As I will attempt to show, a distinction can be drawn on a policy level between "dangerous" defects in buildings and merely "shoddy" construction in buildings and that, at least with respect to dangerous defects, compelling policy reasons exist for the imposition upon contractors of tortious liability for the cost of repair of these defects. ${ }^{12}$

In determining the existence of a tort law duty of care, however, the normative significance of a "dangerous" product or building structure (which, we are told, engages a tort law duty of care) as distinguished from a merely "shoddy" product or building structure (which does not) is, in the context of Serhan, not obvious. While reliance on the defective monitoring system might well have been dangerous (particularly where it displayed an erroneously low reading as opposed to an error message), such danger evaporated when the representative plaintiffs or the other putative class members discovered the defect. At that point, no reasonable user would have relied on the monitoring system. ${ }^{13}$

Lord Goff of Chieveley \& Gareth Jones, The Law of Restitution, 61) ed. (London: Sweet \& Maxwell, 2002) at para. 36-00t [footnotes omitted].

By "subsequent purchaser," we refer to a purchaser after the original purchaser on the distributive chain. The legal significance of this subsequence is that such a purchaser is not in a relationship of privity with the manufacturer and therefore cannot assert a claim for damage under the law of contract. Supra note 2 at para. 12.

lbid.

This was also recognized by Lord Bridge of Harwich in D\&F Estates Lid. v. Church Commissioners for England, [1988] 2 All E.R. 992 (H.L.) at 1006, where he observed:

If the hidden defect in the chattel is the cause of personal injury or of damage to property other than the chattel itself, the manufacturer is liable. But if the hidden defect is discovered before any such damage is caused, there is no longer any room tor the application of the Donoghue v. Stevensisen principle. The chattel is now defective in quality, but is no longer dangerous. It may be valueless or it may be capable of economic repair. In either case the economic loss is recoverable in cuntract hy a buyer or hirer of the chattel entitled to the benefit of a relevant warranty of quality. but is not recoverable in tort by a remote buyer or hirer of the chattel. 
This point has eluded other Canadian courts, most notably the Ontario Court of Appeal in Hughes $v$. Sunbeam Corp. (Canada) Lid.' There, the manufacturer applied to strike a subsequent purchaser's class action, in which he alleged that he and other putative class members had purchased defective ionization smoke alarms. In allowing the claim to proceed, Laskin J.A. said:

A smoke detector that does not detect fires in time for occupants to escape injury is not itself dangerous, but relying on it is. The occupants are lulled into a false sense of security. The threatened harm to persons or property is no less than that from a dangerous defect. In other words, the safety considerations are similar. Safety justified compensating the owner of the apartment building in Winnipeg Condominium to eliminate the dangerously defective cladding. Safety may also justify compensating the owner of a defective smoke alarm to eliminate dangerous reliance on it. ${ }^{15}$

As with the monitoring system in Serhan, however, no reasonable homeowner would rely on such a smoke alarm once the defect was discovered. Similarly, in Winnipeg Condominium, once the cladding was recognized as defective, the "danger" was eliminated because steps could be taken to isolate the area below the cladding until its removal.

Justice La Forest in Winnipeg Condominium anticipated and rejected this criticism as reflective of an "abstract logic."16 Compensation, he held, ought to be extended to the cost of "fixing the defect" thus "putting the [product] back into a non-dangerous state." single statement reveals a flaw in the Supreme Court of Canada's approach to the question of recovery in tort for pure economic loss arising from a defective product. Justice La Forest's use of the term "back" suggests, contrary to the nature of a manufacturing defect such as that in Serhan, that the product was originally in a non-defective state. In fact, the monitoring system in Serhan, like the building structure in Winnipeg Condominium and the smoke alarm in Hughes, was defective ab initio. The plaintiffs are not seeking to restore something, but rather to improve it. This understood, our criticism of Winnipeg Condominium is based on no "abstraction," but rather upon the concrete distinction between restitution in integrum and betterment, without which distinction the law of products liability would operate in a manner that distorts contract law, allowing claimants to use tort law to escape the consequences of a legally insignificant bad bargain. ${ }^{18}$

This is, of course, a general criticism of Winnipeg Condominium and the case law it has engendered. Had Serhan merely involved, Jike Winnipeg Condominium, a claim by plaintiffs who had incurred expense in mitigating or repairing a dangerous defect, it would in our opinion suffer from the same conceptual difficulty which we discern in the requirement of "dangerousness." Serhan would not, in that case, have represented a novel development in the law. The facts of Serhan, however - and in particular certain specific findings made by

it (2002), 61 O.R. (3d) 433 (C.A.) [Hughes].

1" Jbid. ai $443-44$.

1" Winnipeg Condominium, supra nole 2 at para. 40.

1) Ibid. at para. 36.

14 As Stamp L.J. said in Durron v. Bognor Regis United Building Co. Lrd., [1972] 1 All E.R. 462 (C.A.) at 490: "I have a duly not carelessly to put out a dangerous thing which may cause damage to one who may purchase it, but the duty does not extend to putting out carelessly a defective or useless or valueless thing." 
Cullity J. - suggest that even the broad post-Winnipeg Condominium parameters of tort law are being challenged.

First, Cullity J. found no evidence that either of the representative plaintiffs, or any other putative class members, had been injured by using the SureStep meter or the Strips (other than the de minimis pain involved in obtaining additional blood samples). ${ }^{19}$ Secondly, he found that neither representative plaintiff, nor any other putative class members, had actually paid for a SureStep meter or Strips. ${ }^{20}$ In brief, no claimant suffered injury to property or person, nor was any claimant out-of-pocket for the purchase price or the cost of mitigating or repairing the danger. Thus, even with the doctrinal assistance of Winnipeg Condominium, the plaintiffs could not demonstrate legally significant injury.

This point is fundamental. The language of tort law is intimately associated with damage and its remediation - an element of any cause of action which is remarkably absent from the facts of Serhan. Even as a matter of strictly positive law, the function of tort law, whether expressed in the tort of negligence or in any other tort, is to compensate for loss." "[T] principle of recovery in an action for tort," Cory J. held for the majority of the Supreme Court of Canada in Cunningham v. Wheeler, ${ }^{22}$ is "to compensate the injured party as completely as possible for the loss suffered as a result of the negligent action or inaction of the defendant." ${ }^{23}$ Dissenting in part, McLachlin J. (as she then was) affirmed this "fundamental principle":

[T|he plaintiff in an action for negligence is entitled to a sum of damages which will return the plaintiff to the position the plaintiff would have been in had the accident not occurred, in so far as moncy is capable of doing this. This goal was expressed in the early cases by the maxim restinutio in imtegrum. The plaintiff is entilled to full compensation and is not to be denied recovery of losses which he has sustained... [T] [Te ideal of compensation which is at the same time full and fair is met by award ing damages for all the plaintiff's actual losses, and no more. The watchword is restoration; what is required to restore the plaintiff to his or her preaccidem position. ${ }^{24}$

If tort law's engagement contemplates an "accident," "loss" or "injury," then waiver of tort's requirement of a tort logically precludes recovery by the representative plaintiffs and putative class members in Serhan."s

Serhan, supra note 1 at para. 12.

Ibid. at para. 16. One of the representative plaintiffs was provided with a SureStep meter while in hospital. The other had never owned a meter. Both representative plaintiffs' Strips were actually paid for by the Ontario Drug Benefit program. There was no evidence that any other putative class members had paid for the SureStrip meter or the Strips.

This is admittedly a general statement, and one might want to allow for the distinction between torts were damage is required and torts that are actionable per se (such as trespass).

[1994] I S.C.R. 359.

lbid. at 396 [emphasis added].

lbid. at 368-69 [emphasis added].

Indeed, it suggests more generally that Winnipeg Condominium is itself incorreclly decided - there having been neither property damage nor personal injury in that case, but rather the legally insignilicant fact of the plaintifr having purchased a product or a building structure that is less valuable than it had anticipated. Here we are agreeing with Stephen Waddams. in Dimensions of Private Lan: Categories and Concepts in Anglo-American Legal Reasoning (Cambridge: Cambridge University Press. 2003) at 159 [Waddams, Dimensions of Private Lan']. 
One would have expected that our point here - that tort law's engagement requires damage - is sufficiently trite as to merit no reiteration. Serhan suggests, however, that this elemental component needs to be emphasized, particularly in light of the multiple causes of action and remedies pleaded, and of Cullity J.'s ultimate resort to a restitutionary remedy in the mistaken belief that he could do so where there was no damage. A restitutionary remedy does not, in fact, solve the problem he was seeking to avoid in his erroneous conclusion that "waiver of tort" did not presuppose the committal of a tort. For two reasons, Serhan specifically, and cases of defective products generally, cannot be so easily displaced from the law of torts into the law of restitution. First, in Serhan, none of the prospective claimants actually paid for the monitoring system, so any enrichment of the manufacturer did not correspond to a deprivation on their part. That aside, in dangerous defects cases generally, we cannot know whether the subsequent purchaser has suffered a loss within the meaning of unjust enrichment until we also know both the amount that he or she paid for the product or building structure and the value of the product or building structure (accounting for the defect). The price paid, after all, might well have conformed to its value.

Moreover, restitution, like tort law, does not operate to restore a lost bargain in whole or in part by awarding costs of repair (as opposed, for example, to the costs of merely removing the danger). Indeed, Mayo Moran has observed that restitution's emphasis on the defendant's enrichment (rather than the plaintiff's loss) not only affirms the law's traditional (that is, preWinnipeg Condominium) proscription of damages beyond the cost of averting danger, but provides a more satisfying account for it. That is, restitution's inquiry is directed to quantifying the manufacturer's enrichment by the relief from its potential liability engendered by the subsequent purchaser's preventative measures, and that enrichment occurs only to the extent that such measures eliminated the danger posed by the manufacturer's negligence. ${ }^{26}$ Restitution, then, falls short of requiring the defendant to confer a betterment on the plaintiff by furnishing the plaintiff with a qualitatively whole product.

A restitutionary analysis, therefore, does not solve the problem of compensation for manufacturing defects, and it leaves the prospective claimant no further ahead than he or she would be in relying solely on tort law. While Professor Moran has demonstrated that restitution offers a more satisfying account for the law's rationale for recovery for lost bargains, restitution merely affirms the position of tort law and the result it prescribes by focusing on issues of wrongdoing arising from a manufacturer's fault. As such, the application of the law of unjust enrichment would be parasitic to the law of torts.

\section{Why Do We CARE?}

In addition to negligence, the putative class of plaintiffs in Serhan also alleged misrepresentation (fraudulent and negligent) and violations of the Competition Act, ${ }^{21}$ and also, remarkably, sought an order imposing a constructive trust over all revenues that Johnson \& Johnson generated from the sale of the monitoring system. Given this multiplicity of causes of action and remedies pleaded, reaffirmation of the doctrinal confines of private law

3" Mayo Moran, "Rethinking Wimnipeg Condominium: Restitution, Economic Loss, and Anticipatory Repairs" (1997) 47 U.T.L.J. 115 at 156. 
generally - which confines have been challenged and in many cases jettisoned over the past 20 years $^{28}$ - may well emerge over the next few years as an urgent judicial priority should other Serhan-type pleadings appear in ensuing cases. Indeed, Serhan's pleadings reflect the trend in U.S. products liability litigation, most recently instantiated by the plethora of claims against cigarette manufacturers. Justice Cullity, moreover, borrowed from a well-known U.S. source on the law of unjust enrichment in reaching his decision - a 1920 trial decision of the U.S. District Court in Federal Sugar Refining Co. v. United States Sugar Equalization Board $^{29}$ - where it was suggested that a defendant who had wrongfully enriched itself by committing a wrong against the plaintiff must disgorge such enrichment, notwithstanding the plaintiff's inability to quantify its loss.

This, however, goes to the question of the remedy to be ordered, not to the question of whether the plaintiff must prove damage. Indeed, had Cullity J. canvassed U.S. authorities more directly on point, he would not have found support for his conclusion. Most U.S. plaintiffs seeking restitution in defective products cases also allege some common law or statutory tort causing damage, upon whose coattails the restitutionary claim stands. So, for example, claims in deceit and misrepresentation buttressed the plaintiffs' case for restitution in Price v. Philip Morris ${ }^{30}$ — which resulted in a verdict of $\$ 10.1005$ billion. " Other recent examples include actions against Purdue Pharma, the manufacturer of the painkiller Oxycontin, where purchasers alleged detrimental reliance upon a misrepresentation as well as restitution, alleging that they were not told of Oxycontin's potentially addictive properties. ${ }^{32}$ The notion underlying these types of claims is that the consumers would not have paid the price they paid had they known of the product's true qualities. For that reason, they seek the difference in price between what they actually paid and the product's "true" value (being its subjective value to the plaintiffs).

Our point here, however, is that tort law's fundamental precepts are observed and enforced in U.S. litigation, even in the face of notoriously fierce scattergun pleading. This may be a function of a more rigourously doctrinal culture in the U.S. litigation setting. Alternatively, doctrinal fidelity is perhaps being employed by U.S. judges as a control mechanism in respect of multiplying and increasingly creative products liability lawsuits. In other words, orthodoxy governs not just in the face of scattergun pleading, but because of it. In any event, if Serhan represents a harbinger of U.S. style products liability pleadings in Canada, tort law's fundamental precepts may start to matter again.

Lewis N. Klar, “Judicial Activism in Private Law" (2001) 80 Can. Bar Rev. 215.

268 F. 575 (S.D.N.Y 1920).

Price v. Philip Morris, 2003 WL 22597608 (III. Cir. 2003) (WL).

There, a class of over one million plaintiffs successfully proved that Philip Morris had misrepresented its "light" cigarettes as being less of a health risk than regular cigarettes. despite its knowledge that any benefits would be offset by smokers using more "light" cigarettes or inhaling longer, thereby increasing their intake of tar and nicotine available in regular cigareltes. The judge found that the company intentionally deceived consumers and ordered Philip Morris 10 disgorge 92 percent of its revenuts. Significantly, there was no evidence that smokers of "light" cigaretles had higher cancer rales or suffered adverse health effects different from regular smokers; their only claim was that they paid more than would have otherwise. The case is under appeal at the Illinois Supreme Court. For a comprehensive treatment of no-injury lawsuits in the U.S. (including the Philip Morris case) see Moin A. Yahya. "Can I Sue Without Being Injured?: Why the Benefit of the Bargain Theory for Product Liability is Bad Liw and Bad Economics" (2005) 3 Geo. J.L. \& Pub. Pol'y 83.

Williams v. Purdue Pharma. Co. 297 F.Supp.2d 171 (D.D.C. 2003). 


\section{Conclusion}

The U.S. path respecting pure economic loss in the products liability setting is, of course, different from that followed by Canadian courts since Winnipeg Condominium. Generally, claims for damages arising from the mitigation or repair of a defect, dangerous or otherwise, have been unsuccessful: with the exception of Price v. Philip Morris and one appellate decision from Massachusetts (also involving Philip Morris), ${ }^{33}$ all such claims in the U.S. including claims which, like Serhan, involved a potentially dangerous defect in medical equipment ${ }^{34}$ - have been either dismissed at trial or on appeal. ${ }^{35}$ This does not mean, however, that we have nothing to learn from the U.S. experience. Where litigants engage multiple causes of action and remedial options, the judicial role may necessarily become one of preserving private law's doctrinal coherence, to ensure that one area of private law (for example, torts) is not distorted by the court's employment of another (for example, restitution or contract).

Such a role may well be controversial to jurists, accustomed as we have become to rejecting orthodox classification of obligations. ${ }^{36}$ In the area of products liability, however, where the governing principles already constitute a mixture of imposed statutory warranties, contract and negligence law, and now where Canadian plaintiffs have sought to apply the constructive trust, doctrinal boundaries may become critical, even only as a judicial administrative imperative to control the proliferation and complexity of products liability litigation.

Aspinall v. Philip Morris Companies, 813 N.E.2d 476 (Mass. Sup. Ct., 2004). For a critique of the Aspinall decision, see Victor E. Schwartz \& Leah Lorber, "State High Court Ruling Departs From Tort Principles in Consumer Protections Cases" (2005) 20:4 Legal Backgrounder , online: Washington Legal Foundation <www.wlf.org/upload/0 1 1405LBSchwartz.pdf>.

Angus v. Shiley, Inc., 989 F.2d 142 (3rd Cir. 1993). There, a plaintiff who had a heart valve implanted in her heart learned that other heart valves manufactured by llie defendant had been defective causing injury or death. Although her valve was not defective, she sued the manuficturer claiming physical and mental ailments as a result of her anguish resulting from learning about the fraudulent concealment. The trial court dismissed her case, and it was affirmed on appeal. The Alabama Supreme Court and a California intermediate appellate court also dismissed similar cases brought in their jurisdictions: Pfizer. Inc. v. Farsian, 682 So.2d 405 (Ala. S.C. 1996); Khan v. Shiley /nc., 266 Cal. Rptr. 106 (App. 1990). See also Ziegelmann v. DaimlerChrysler, 649 N.W.2d556(N.D.S.C. 2002); Frank v. DaimlerChrysler, 741 N.Y.S.2d 9 (S.C.A.D. 2002)); Rivera v. Wyeth-Ayerst Lab., 283 F.3d 315 (5th Cir. 2002); Yuv. International Business Machines Corp., 732 N.E.2d 1173 (III. App. 2000); Jarman v. United Industries, 98 F.Supp. 2d 757 (S.D. Miss. 2000); Brieht v. General Morors. 172 F.3d 623 (8th Cir. 1999); Ford Motor Co. v. Rice, 726 So. $2 \mathrm{~d} 626$ (Ala. S.C. 1998); In re Air Bag Products Liability Liligation, 7 F.Supp. 2 d 792 (E.D. La. 1998); Weaver v. Chrysler. 172 F.R.D. 96 (S.D.N.Y. 1997): Verb v. Motorola, 672 N.E.2d 1287 (III. App. 1996); American Sutsuki Motor v. Superior Courrt. 14 Cal. Rptr.2d 526 (App. 1995); Carison v. General Motors, 883 F.2d 287 (4th Cir. 1989).

For yet another recent example involving Philip Morris, see the Florida District Court of Appeal's dismissal of a similar claim in Philip Morris USA v. Hines, 883 So.2d 292 (Fla. Dist. Ct. App. 2003). Sec Waddams, Dimensions of Private Law, supra notc 25. For a critical appraisal of this trend, sce Stephen A. Smith, "Taking Law Seriously" (2000) 50 U.T.L.J. 241: and Stephen A. Smith, "A Map of the Common Law?" (2004) 40 Can. Bus. L.J. 364. 